\section{Historia Polityka}

Irr (8), wiosna 2009

\title{
Karykatura polityczna jako źródło do badań nad historią Drugiej Rzeczypospolitej Postulaty badawcze
}

$P$ rzystępując do pisania niniejszego artykułu wyznaczyłem sobie jeden, podstawowy cel badawczy. Będę się starał poddać opinii czytelnika postulaty badawcze, przydatne jak mniemam w pracy nad dość specyficznym źródłem historycznym-wizualnym, jakim jest karykatura ${ }^{1}$.

* Redaktorzy tomu, chcieliby podkreślić, iż wielu autorów sugeruje, aby historyk myśli politycznej uwzględniał w swoich badaniach zagadnienia filozofii, socjologii, dziejów literatury, historii sztuki, gdyż jak zauważył Stanisław Filipowicz: „Zrozumienie komplementarności wielu rozmaitych dziedzin jest rzeczą o wiele ważniejszą, aniżeli zastosowanie jakiegoś redukcjonistycznego schematu odpowiadającego prawidłom scjentystycznej, metodologii". Uwagę tę, zdaniem redakcji, można odnieść do sfery ikonografii, w tym również do tak specyficznego źródła jakim jest karykatura.

${ }^{1}$ W niniejszym studium świadomie pomijam kwestię wyartykułowania problematyki występującej w polskiej karykaturze w latach 1918-1939. Uważam, że ten problem powinien znaleźć się w osobnym znacznie przekraczającym ramy artykułu kompleksowym opracowaniu. Pozwolę sobie jednak dokonać kilku uwag o charakterze porządkującym. Przede wszystkim nie jest możliwe podanie dokładnej liczby karykatur, które mogą się okazać przydatne. Z pewnością ich liczba oscyluje wokół kilku tysięcy. Niezbędny materiał źródłowy powinien jednak pochodzić z trzech „kanałów”: prasy (codziennej o profilu polityczny, prasy codziennej informacyjnej, pism humorystyczno-satyrycznych), katalogów z wystaw karykatury i rysunku satyrycznego oraz zwartych wydawnictw, zwłaszcza tek i albumów zawierających rysunek satyryczny. Prawem autora przytoczę kilka przykładów. Z pism satyryczno-humorystycznych nie można pominąć: „Muchy”, „Cyrulika Warszawskiego”, „Wróbli na Dachu”, „Szpilek”. Kwerenda prasy codziennej powinna obejmować najważniejsze tytuły, na przykład: „Kurier Poznański”, „Kurier Poranny”, „Gazeta Warszawska”, „Ilustrowany Kurier Codzienny”, „Tygodnik Ilustrowany”, „Wiadomości Literackie”, „Robotnik”. Dokładne informacje na temat pracy przytaczają między innymi: 
„Dla zrozumienia społecznej roli komizmu, jego miejsca w kulturze, niezbędna jest świadomość, iż tworzy on rodzaj wspólnoty [...] śmiechu. Jest to wspólnota połączona szczególną więzią społeczną, nieraz jak się przekonamy - o charakterze trwałym, a nawet sformalizowanym. Jest to zarazem wspól-

A. Paczkowski, Prasa polska 1918-1939, Warszawa 1980; Idem, Prasa codzienna Warszawy w latach 1918-1939, Warszawa 1983; Idem, Prasa Drugiej Rzeczypospolitej (1918-1939). Ogólna charakterystyka statystyczna, Rocznik Historii Czasopiśmiennictwa Polskiego, 1972, R. 11, z. 1; A. Notkowski, Polska prasa prowincjonalna Drugiej Rzeczypospolitej (1918-1939), Warszawa-Łódź 1982; W. Pepliński, Prasa pomorska w Drugiej Rzeczypospolitej 1920-1939, Gdańsk 1987; B. Wysocka, Wielkopolska prasa regionalna w Drugiej Rzeczypospolitej, Rocznik Historii Czasopiśmiennictwa Polskiego, 1976, R. 15, z. 3; P. Nowak, Poznań jako ośrodek wydawniczy w dwudziestoleciu międzywojennym 1919-1939, Poznań 1997; J. Jarowiecki, B. Góra, Prasa lwowska $w$ dwudziestoleciu międzywojennym. Próba bibliografii, Kraków 1994. Z katalogów wystaw zorganizowanych przed wybuchem II wojny światowej warto wymienić: Katalog wystawy pośmiertnej karykatur politycznych Kazimierza Kostynowicza, Warszawa 1929; Karykatury Kazimierza Sichulskiego. Katalog wystawy, oprac. A. Schroder, Lwów 1918; Katalog karykatur Kazimierza Sichulskiego. Restauracja hotelu Sportu St. Kasprowicza katalogów syna, wstęp L. Solski, Cieszyn 1928; Katalog prac Kazimierza Sichulskiego, wstęp W. Terlecki, Kraków 1934. Z katalogów wystaw zorganizowanych po wojnie na uwagę zasługują: Niemcy i Polacy. Od obrazu wroga ku pojednaniu. Satyryczne vis-a-vis (1848-1991), wstęp T. Szarota, W. Wrzesiński, Warszawa 1991; Czasy wojen i pokoju. Karykatura polska 1914-1939, wstęp W. Chmurzyński, Warszawa 2004; Zdzisław Czermański 1900-1970. Rysunki, Galeria Kordegarda, Warszawa 1991; Lata dwudzieste, lata trzydzieste..., Warszawa 1989; E. Lipiński, Katalog wystawy jubileuszowej, Warszawa 1988; Antoni Wasilewski (1905-1975). Wystawa malarstwa i rysunków, Kraków 1977; „Szpilki” 1935-1955. Wystawa, Warszawa 1956; „Szpilki” 1935-1960. Wystawa, Warszawa 1960; „Szpilki”. Sześćdziesiąt lat, Warszawa 1995; Ostrożnie z ogniem! Wystawa polskiej karykatury antywojennej 1925-1960, Warszawa 1960. Albumy, teki i opracowania: Marszałek Piłsudski w 13 karykaturach Zdzisława Czermańskiego, Paryż 1931; G. Rogalski, Album karykatur marszałka Józefa Piłsudskiego na pamiątkę X-lecia Niepodległości Rz.Posp. Polskiej 1914-1928, Kraków 1928; „Mein Kampf”. Rysunki i wiersze Gustawa Rogalskiego, b.m.w., 1939; Gabinet Witosa rysunkiem Zygmunta Skwirczyńskiego, Warszawa 1920; Karykatury sejmowe. Autolitografie Zygmunta Skwirczyńskigo, z. 2, b.m.w, b.d.w.; Karykatury sejmowe. Autolitografie Zygmunta Skwirczyńskiego, z. 3, b.m.w, b.d.w.; Karykatury sejmowe. Autolitografie Zygmunta Skwirczyńskiego, z. 4, b.m.w; b.d.w; K. Sichulski, Karykatury współczesne, Kraków 1918; Wojsko w karykaturze. Z teki karykatur Jotesa, Warszawa b.d.w; Z cyklu karykatur Jotesa (Jerzego Szwajcara). Wojsko w karykaturze, Seria A, Warszawa 1922; Z cyklu karykatur Jotesa (Jerzego Szwajcara). Wojsko w karykaturze, Seria C, Warszawa 1922; Z cyklu karykatur Jotesa (Jerzego Szwajcara). Wojsko w karykaturze, Seria D, Warszawa 1922; Ministerstwo Komunikacji. Album karykatur Jotesa, b.m.w., 1938; Album karykatur Ministerstwa Opieki Społecznej w wykonaniu Jotesa, Warszawa 1939; Album karykatur Ministerstwa Skarbu w wykonaniu Jotesa, Warszawa 1939; Szczutek, Cyrulik Warszawski, Szpilki 1919-1939, oprac. E. Lipiński, Warszawa 1975; „,Szpilki” 1935-1965. Coś nam zostało z tych lat..., wybór i oprac. E. Lipiński, Warszawa 1967; A. Garlicki, J. Kochanowski, Józef Piłsudski w karykaturze, Warszawa 1991; Prosto z wiejskiej. Sejm i Senat II Rzeczypospolitej w karykaturze i satyrze, wyboru dokonał i szkicami poprzedził A. Zakrzewski, Wrocław-Warszawa-Kraków 1990. 
nota kulturowa, podobna do tej, która jaką wytwarza język. Znaczna część twórczości komicznej zawarta jest w formach literackich i wykorzystuje język, jego cechy i właściwości do osiągnięcia swoich celów" - pisał ceniony polski socjolog Kazimierz Żygulski². Jednym ze środków przekazu komicznej sytuacji, wywołującej, pobudzającej do śmiechu jest karykatura. Karykatura śmieszy, wyczula na opisywana rzeczywistość, wyszydza, wykpiwa, naigrywa się, drwi, natrząsa się, prześmiewa, ale również przestrzega, ostrzega, pełni rolę moralnej matrycy wyczulając na treści etyczne. Może stanowić pobudkę do obyczajowych przeobrażeń, zohydzać erotyczno-pornograficznym przekazem. Karykatura może być również wartością samą w sobie, interpretowaną przez pryzmat estetyki, plastycznej formy piękna lub brzydoty. Wreszcie karykatura może stać się skutecznym orężem w walce politycznej, narzędziem propagandy reżimu, obozu rządzącego czy lidera-przywódcy politycznego wykorzystywanym do ośmieszenia przeciwnika-wroga, wyszydzenia jego cech osobowościowych, pochodzenia społecznego, ideałów które wyznaje, z drugiej jednak strony może integrować, łączyć we wspólnotę. Przytoczona przeze mnie transkrypcja jest oczywiście bardzo ogólna nieprecyzyjna i wieloznaczna, wymaga zatem uściślenia pojęcia „karykatura”. I tak, według „Słownika Języka Polskiego” - „karykatura” jest to: „przesadne, ośmieszające uwydatnianie i wyolbrzymianie charakterystycznych cech postaci, przedmiotów lub wydarzeń w sztukach plastycznych (głównie w rysunku i grafice) lub w utworze literackim (głównie w satyrze); także rysunek lub utwór przedstawiający kogoś lub coś w taki przesadny ośmieszający sposób”3. Natomiast w „Wielkiej Ilustrowanej Encyklopedii Powszechnej” czytamy, iż karykatura pochodzi od włoskiego caricare, co znaczy „przesadzać, sposób przedstawiania przedmiotów specjalnie jednak osób z podkreśleniem przesadnem jakiejś cechy. Przedmiotem karykatury mogą być poszczególne postacie, klasy społeczne czy też typy narodowe"4. Jeszcze inną definicję karykatury przytacza jeden z nestorów polskiej karykatury: „W znaczeniu najogólniejszym, karykatura jest syntezą uwidocznionego wyrazu oraz charakteru istoty żyjącej lub przedmiotu, wyrażoną w plastycznie w sposób pro-

${ }^{2}$ K. Żygulski, Wspólnota śmiechu. Studium socjologiczne komizmu, Warszawa 1976, s. 15. Na temat społecznej roli komizmu i śmiechu pisali obszernie: H. Bergson, Śmiech. Studium o komizmie, Warszawa 1902; S. Szuman, O dowcipie i humorze, Warszawa 1936; J. St. Bystroń, Komizm, Lwów 1938; B. Dziemidok, O komizmie, Warszawa 1967.

3 Uniwersalny Słownik Języka Polskiego, red. S. Dubisz, Warszawa 2002, t. 2, s. 203. Podobnie w Słowniku Wyrazów Obcych, pod red. J. Tokarskiego, Warszawa 1980, s. 345.

${ }^{4}$ Wielka Ilustrowana Encyklopedia Powszechna, t. VII, Kraków 1995 (reprint), s. 201. 
sty, dosadny, oryginalny i dowcipny a przede wszystkim w sposób jaskrawy, frapujący wyobraźnię" ${ }^{5}$.

W nauce angloamerykańskiej termin cartoon oznaczający rysunek satyryczny, film rysunkowy będący składnikiem pictorial communication odróżnia się świadomie od pojęcia caricature, co znaczy rysunek wyolbrzymiający lub pomniejszający niektóre cechy osoby lub rzeczy ${ }^{6}$. A zatem brytyjskie rozumienie pojęcia karykatura należałoby raczej łączyć z polskim wyjaśnieniem prezentowanym w rodzimych słownikach i encyklopediach. Dzieje karykatury sięgają czasów najdawniejszych. Są tak stare, jak stary jest komizm i potrzeba śmiechu. Jednak dopiero na przełomie XVI i XVII wieku wytworzyła się sztuka rysunku satyrycznego bliższa współczesnemu pojęciu karykatury. Już na początku XVIII wieku w Europie zaczęły się ukazywać czasopisma humorystyczno-satyryczne, w których umieszczano karykatury. Pierwowzorem miał być holenderski „Ezop w Europie”. W 1754 r. Beniamin Franklin podał do wiadomości publicznej znany i wielokrotnie przywoływany rysunek „Jon or Die”, który przez współczesnych uważany jest za archetyp karykatury politycznej. W wieku osiemnastym rozpoczęto również gromadzić, kolekcjonować karykaturę społeczną i polityczną. Pionierem był francuski arystokrata J. M. Boyer-Brun, który w 1792 roku wydał pokaźny tom rysunków satyrycznych z okresu rewolucji francuskiej opatrzonych autorskim komentarzem. W wieku XIX rysunek satyryczny obecny był już na łamach prasy codziennej oraz pism satyryczno-humorystycznych, które stawały się coraz bardziej popularne. W 1830 r. we Francji zaczął wychodzić tygodnik „La Caricature” (wyd. Ch. Philpon), w 1832 r. „Charivari”. W Anglii ukazywał się od 1841 r. „Punch”, w Niemczech niezwykłą popularność uzyskały „Fliegende Blatter”, „Simpliissimus”, „Kladderadatsch”. W Rosji najbardziej poczytne były „Budilnik” (1865-1917) oraz „Satirikon” (1908-1913). Początki polskiej karykatury sięgają XVIII wieku. Rysunki satyryczne i karykaturalne zamieszczano w „Monitorze” (1765-1785), a sławą cieszyli się D. Chodowieki, J. P. Norblin, M. Płoński, A. Orłowski, A. Oborski, J. Sokołowski. W XIX wieku dużą poczytność osiągnęły: „Mucha” (1868-1952), „Diabeł” (1869-1922), „Szczutek” (1869-1896). Oazą śmiechu stała się Galicja, gdzie jeszcze przed 1918 r. ukazywało się kilkadziesiąt pism tego typu. Natomiast najmniejszą popularnością pisma satyryczne cieszyły się w byłym za-

\footnotetext{
${ }^{5}$ Jotes (Jerzy Szwajcer), Okiem karykaturzysty, Warszawa 1926, s. 3.

${ }^{6}$ Obszerniej: W. Głodkowski, Karykatura polityczna jako forma komunikowania w badaniach amerykańskich, Zeszyty Prasoznawcze, 1988, R. XXIX, nr 3, s. 29-30.
} 
borze pruskim ${ }^{7}$. Po odzyskaniu niepodległości w Polsce funkcjonowało około 300 pism satyrycznych. Największe znaczenie miały: lwowski „Szczutek” (A. Altenberg, S. Wasylewski, H. Zbierzchowski, K. Sichulski, Z. Czermański, A. Świdwiński, J. Szwajcar-Jotes, E. Głowacki), stołeczny „Cyrulik Warszawski” (L. Fiszer, L. Serafinowicz, Z. Czermański, W. Daszewski, F. Topolski), redagowany przez „prawicową” spółkę wydawniczą A. Sadzewicza i M. Niklewskiego tygodnik „Szopka” (W. Perzyński, J. Bandrowski); sięgająca swoimi korzeniami wieku XIX „Mucha”, krakowskie „Wróble na Dachu” (A. Wasilewski, K. Ferster-Charlie, J. Zaruba, M. Piotrowski) oraz współtworzony przez młodą liberalną inteligencję o wyraźnie lewicowych przekonaniach tygodnik satyryczny „Szpilki” (Z. Mitzner, E. Lipiński, B. Bocianowski, F. Parecki, A. Siemaszko, J. Srokowski, M. Berezowska). Ukazywały się równi eż regionalne efemerydy satyryczno-humorystyczne. Różnego rodzaju: „Pająki”, „Pręgierze”, „Filuty”, „Bociany”, „Chochoty”, „Arbuzy”, „Diabły”, „Borty”. Interesujące karykatury zamieszała również prasa codzienna. Nie sposób oczywiście wymienić wszystkich. Jednakże tytułem przykładu warto wspomnieć o: „Robotniku”, „Kurierze Poznańskim”, „Dzienniku Bydgoskim”, „Kurierze Polskim”, „Nowym Kurierze”, „Gazecie Pomorskiej”, „Ilustrowanym Kurierze Codziennym”, „Tygodniku Ilustrowanym”. Na potrzeby niniejszego studium należa-

7 Obszernie na temat historii karykatury piszą: J. Topass, Szlakami dusz twórczych. Sylwetki i szkice, Warszawa b.d.w.; B. Nadolski, Lwowskie czasopiśmiennictwo humorystyczne w XIX wieku, Kurier Literacko-Naukowy, 45 (1934); W. Husarski, Karykatura w Polsce, Warszawa 1926; H. Górska, E. Lipiński, Z dziejów karykatury polskiej, Warszawa 1977; Z. Dżedżyk, Poznańskie efemerydy satyryczne z roku 1862, Kwartalnik Historii Prasy Polskiej, 1980, t. XIX, z. 3, 1980; Idem, Satyryczne czasopisma Wielkiej Emigracji (Paryż 1832-1845), Kwartalnik Historii Prasy Polskiej, 1977, t. XVI, z. 1; E. Skorupa, Obraz Galicji w satyrze politycznej lwowskiego „Sztuczka”, Kwartalnik Historii Prasy Polskiej, 1989, t. XXVIII, z. 2; Idem, Dziennikarstwo satyryczne w optyce satyryczne lwowskich czasopism humorystyczno-satyrycznych drugiej połowy XIX wieku, Kwartalnik Historii Prasy Polskiej, 1989, t. XXVIII, z. 1; M. Tobera, Prasa satyryczno-humorystyczna w Królestwie Polskim w latach 1905-1907, Kwartalnik Historii Prasy Polskiej, 1984, XXIII, z. 3; T. Krzyżewski, Weterani lwowskiego czasopiśmiennictwa humorystycznego, Rocznik Historii Czasopiśmiennictwa Polskiego, 1976, R. 15, z. 2; Idem, Księga humoru lwowskiego. Teoria, dzieje i antologia humorystyki lwowskiej z lat 1880-1944. Komedie, Fraszki, Żarty, Piosenki, Karykatury, Warszawa 1995; H. Tadeusiewicz, „Motyl” (1828-1831) - warszawskie pismo literacko-rozrywkowe, Rocznik Historii Czasopiśmiennictwa Polskiego, 1972, R. XI, z. 3. Wśród wydawnictw obcojęzycznych warto przywołać następujące: Champfleury, Historie generale de la caricature, Paris 1865-1880; A. B. Maurice, F. T., Cooper, The History of Nineteenth Century in Caricature, b.m.w. 1904; M. Horn, The World Encyklopedia of Cartoons, New York 1980.

${ }^{8}$ Na temat czasopism humorystyczno-satyrycznych w dwudziestoleciu międzywojennym odrębne studia poświęcili: Z. Mitzner, L. Pasternak, Satyra prawdę mówi... 1918-1939, Warszawa 1963; I. Witz, J. Zaruba, 50 lat karykatury polskiej 1900-1950, Warsza- 
łoby kilku zabiegów porządkujących. Wykorzystanie karykatury politycznej jako źródła do badań nad historią polityczną jak i socjologicznym ujęciem dziejów jest w Polsce nader skromne. Właściwe poza pionierskimi studiami T. Szaroty, polscy uczeni traktują rysunek satyryczny w kategoriach wytworu masowej kultury, a co za tym idzie masowej komunikacji ${ }^{9}$. Zgoła inne nastawienie panuje w Europie Zachodniej (zwłaszcza we Francji, Niemczech, Anglii) oraz USA. Badania nad karykaturą mają tam charakter interdyscyplinarny. Obecne są zarówno w nauce historycznej, jak i komunikologii, politologii, socjologii, psychologii społecznej, antropologii kultury czy nauce o reklamie politycznej i marketingu politycznym. Skromna płaszczyzna metodologiczna w rodzimych badaniach powoduje jednak, że każda propozycja warsztatowa wydaje się być dyskusyjna. Niemniej należy dokonać kilku istotnych zabiegów metodologicznych celem prezentacji postulatów badawczych.

Po pierwsze musimy rozróżnić społeczną, obyczajową karykaturę od karykatury politycznej, która nas tutaj będzie interesować. Po drugie badania nad karykaturą polityczną wymagają sprecyzowania tego pojęcia. Pod pojęciem karykatury politycznej będę rozumiał przekaz wizualny (rysunek satyryczny) stanowiący zarówno rodzaj komunikacji między nadawcą a odbiorą, jak również element publicystycznej wypowiedzi przy zastosowaniu określonych środków. Musimy być świadomi, że karykatura polityczna nie może być traktowana jedynie w kategorii komunikacji - przekazu między nadawcą a odbiorcą. Takie postrzeganie byłoby w dużej mierze ubogie i tylko w części zasadne. Karykatura w warsztacie pracy historyka jest również przekazem publicystycznym o charakterze wizualnym. Mniejsze znaczenie odgrywać będzie oczywiście sfera doznań estetycznych, a cała uwaga koncentrować się będzie na treści (fabule) przekazu. Znany przedwojenny karykaturzysta i autor interesujących wspomnień J. Szwajcar-Jotes pisał: „Karykatura jest jeno środkiem ekspresji artystycznej i nie należy jej pod żadnym pozorem utoż-

wa 1961; J. Białostocki, Polska grafika użytkowa 1900-1939. Próba charakterystyki, [w:] Z zagadnień plastyki polskiej w latach 1918-1939, Studia z historii sztuki, pod red. J. Starzyńskiego, t. IX, 1963; Z. Mitzner, Kilka uwag o karykaturze polskiej, o jej tradycjach, tradycjach jej teraźniejszości i przyszłości, Przegląd Artystyczny, nr 5, 1951; B. Piątkowski, Uwagi o wspótpracownikach polskiej prasy humorystyczno-satyrycznej dwudziestolecia międzywojennego, Rocznik Historii Czasopiśmiennictwa Polskiego, 1976, R. XV, z. 3; W. Filer, E. Lipiński, Z dziejów cnoty, „Szpilki” 1935-1985, Warszawa 1985.

9 T. Szarota, Polak w karykaturze niemieckiej (1914-1944). Przyczynek do badań stereotypów narodowych, [w:] Wokół stereotypów Polaków i Niemców, pod red. W. Wrzesińskiego, Wrocław 1991, s. 69-93 (ten sam tekst w: T. Szarota, Niemcy i Polacy. Wzajemne postrzeganie i stereotypy, Warszawa 1996, s. 101-126. 
samiać z tem o się zwykło nazywać „rysunkiem humorystycznym” lub „karykaturą polityczną". Punkt ciężkości rysunku humorystycznego lub karykatury politycznej tkwi w fabule, w idei, nieraz w groteskowym ujęciu pomysłu lub w sztucznem zniekształceniu obiektu [...] t.zw. karykatura polityczna jest po prostu ilustrowaną satyrą polityczną. I tutaj również punkt ciężkości tkwi w idei, w dowcipie, nie zaś w samym rysunku. Rysunek odgrywa tu rolę raczej pomocniczą, rolę czynnika działającego bezpośrednio na wyobraźnię, a przez to samo znakomicie ułatwiającego rozumienie wysuniętej idei"10.

Dokonując zabiegów warsztatowych powinniśmy wskazać na podstawowe funkcje karykatury politycznej:

1. Funkcja rozrywkowa. Funkcja rozrywkowa wydaje się być dla badacza z pozoru błaha. Nic bardziej mylnego. Jest to podstawowa funkcja i zadanie satyry-groteski-rysunku satyrycznego. Stwierdzenie, że przekaz karykaturalny śmieszy wydawać się może banałem. W gruncie rzeczy symbolika, w jaką zaopatrzona jest karykatura, a nie rzadko również jej cześć werbalna, czyli podpis pod rysunkiem wywołuje śmiech, a więc tworzy sytuację komiczną. W mniejszym stopniu cieszy forma, czy styl jakim wykonano rysunek, a bardziej jego treść. Tutaj koncentruje się cała uwaga odbiorcy. Reakcja na śmiech, a więc inspiracja nieokiełzanej radości jest możliwa tylko wówczas, kiedy zarówno nadawca (autor rysunku), wspierany, inicjowany przez określoną orientację polityczną, jak i odbiorca pozostają w tym samym kręgu kulturowym, w którym symbole i fabuła wydają się być zrozumiałe. Istotne dla rozumienia funkcji rozrywkowej jest jej umoralniające oddziaływanie. Jeśli przyjmiemy, że w karykaturze wykpiwane i wyśmiewane są ludzkie przywary, egoizm polityków, nurtów politycznych, to reakcja zawstydzenia, jeśli taka wystąpi stanowi czynnik umoralniający. Nierzadko pod wpływem karykatury osoby, które stały się jej bohaterami próbowały mentalnej zmiany. Zawstydzenie wywołane śmiechem oraz komizm sytuacyjny może powodować moralne oczyszczenie, a przynajmniej powzięcie obietnicy o „poprawie”. Wspólna ocena przez czytelników-odbiorców, „perswazyjne potępienie” danej sytuacji czy opinia o danym polityku może być konstruktywna. Kara za wyszydzenie i wyśmianie okazuje się wówczas zbawienna - „naprawcza”.

2. Funkcja socjologiczna. Rysunek satyryczny ma skłaniać do przemiany struktury społecznej, grup społecznych, partii i stronnictw politycznych. Symbolika i „gra znaków”, jaką posługuje się karykaturzysta ma skłonić do zmiany, reorientacji, przebudowy. W tym aspekcie ważną rolę odgrywa-

${ }^{10}$ Jotes (Jerzy Szwajcer), op. cit., s. 2-3. 
ją symbole zrozumiałe dla danego kręgu kulturowego, w którym występują. Umieszczenie tych symboli w kontekście politycznym pełni podwójną rolę. Po pierwsze w sposób komicznym, ale za pomocą sugestywnej perswazji podaje komentarz polityczny do bieżącej sytuacji politycznej lub zachowania danego polityka. Po drugie karykatura pokazuje jaki jest odbiór społeczny przekazu („komunikat zwrotny”?). Może dać odpowiedź na pytanie czy rysunek ograniczy, zniweluje społeczną agresję. Z drugiej jednak strony karykatura może modyfikować zachowania społeczne członków partii politycznej, która wpisała się w fabułę przekazu, stanowiąc jej oś.

3. Funkcja kreacji i porządkowania rzeczywistości społeczno-politycznej. Większość karykatur politycznych publikowanych w czasopismach II Rzeczypospolitej opisywała aktualne wydarzenia polityczne. W tej materii karykatura segmentowała ważność poszczególnych wydarzeń. Nierzadko wydarzenia drugo i trzecioplanowe w przekazie karykaturalnym pretendowały do rangi najważniejszych. Polscy karykaturzyści w interesującym nas okresie szczególnie wiele miejsca poświęcali wydarzeniom politycznym ważnym ze społecznego punktu widzenia. Rację ma W. Głogowski pisząc, że rola „różnych środków komunikowania wzrasta, gdy poruszają one tematy pozostające w sferze osobistego doświadczenia odbiorców" ${ }^{11}$. W ten sposób rysownicy w dużej mierze kreowali otaczającą ich rzeczywistość i poddawali ją zabiegowi porządkującemu. Karykatura w celu porządkowania rzeczywistości zawiera maksymalnie skondensowaną formę, możliwie zrozumiał system znaków i symboli oraz klarowną fabułę. Aczkolwiek zdarzały się zastosowane przez polskich karykaturzystów aluzje, przenośnie i metafory niezrozumiałe dla przeciętnego śmiertelnika, a stanowiące dla współczesnego badacza pole do popisu. Pojawiały się również często karykatury nie wartościujące, pozbawione języka perswazyjnego, a jedynie wskazujące na przebieg procesów i wydarzeń, unikające kategoryzacji. Badacz musi być jednak świadomy, że karykatura polityczna unika dogłębnej analizy, daje tylko temat-impuls. A zatem jest powierzchowna, a nawet nieuporządkowana. Gdyby podjąć się analizy działań politycznych Józefa Piłsudskiego w latach 1926-1935 tylko na podstawie karykatury politycznej zawartej w prasie o prawicowych (endeckich) konotacjach to marszałek Piłsudski wyrósłby na dyktatora rangi J. Stalina czy A. Hitlera. Tak, więc karykatura unika dogłębnej, pełnej analizy, bazuje natomiast na połowiczności, w pewnej mierze sensacji, na tym co w danej chwili może zainteresować odbiorcę. Chwyta się sugestywności i perswazji,

${ }^{11}$ W. Grodkowski, op. cit., s. 44. 
emocji i jaskrawości w przekazie. Często operuje dychotomicznym schematem: „czarno-biały” - „swój -obcy”. Znaczenie karykatury wzrasta wówczas, kiedy ranga przedstawianych wydarzeń staje się dla odbiorców ważna i społecznie potrzebna, modelując ich zapatrywanie na bieżącą sytuację. Można z dużą dozą prawdopodobieństwa stwierdzić, że tego typu przekaz pełnił rolę miernika badania opinii publicznej oraz społecznej akceptacji bądź sprzeciwu wobec sytuacji politycznej, sposobu prowadzenia kampanii wyborczej, polityki reżimu, etc. ${ }^{12}$. Osobnym zagadnieniem ważnym dla kreacji i porządkowania rzeczywistości był wpływ politycznej karykatury na kształtowanie stereotypów i ich lokację w społecznej świadomości. Pojęcie „stereotyp" rozumiem za Walterem Lippmannem jako generalizację, którą posługują się jednostki, a która ujawnia się również w opinii publicznej. Stereotyp był dla Lippmanna, pisze B. Ociepka „zjawiskiem zdecydowanie negatywnym, gdyż zawierał uproszczoną i często fałszywą wizję rzeczywistości, trudną do wykorzenienia, gdyż niosącą za sobą duży ładunek emocji”"13. W zależności

12 Według W. Lippmanna, autora wydanej w 1922 r pracy pt. Public Opinion, „opinię publiczną stanowią obrazy wzajemnych stosunków między ludźmi, ich potrzeby zamierzenia oraz obrazy samych ludzi powstałe w ich umysłach". Za: S. Kuśnierski, Teoretyczne problemy propagandy i opinii publicznej, Warszawa 1980, s. 211.

${ }_{13}$ B. Ociepka, Opinia publiczna, [w:] B. Dobek-Ostrowska, J. Fras, B. Ociepka, Teoria i praktyka propagandy, Wrocław 1999, s. 71. Szczegółowej analizie koncepcję W. Lippmanna poddaje Z. Gostkowski, Teoria stereotypu i poglądy na opinię publicznq Waltera Lippmanna, Archiwum Historii i Myśli Społecznej, t. 5 (1959), s. 39-84. W Polsce „pionierem" badań nad stereotypami był J. Chałasiński, autor nader interesującego studium pt. Antagonizm polsko-niemiecki w osadzie fabrycznej „Kopalnia” na Górnym Śląsku, Przegląd Socjologiczny, 1/2 (1932). Obecnie mamy wiele rozpraw poświęconych stereotypom. Na przykład: A. Siciński, Stereotypy krajów, narodów i mężów stanu, Kultura i Społeczeństwo, 2 (1967); A. Sosnowski, J. Walkowiak, Kierunki badań i rozważań nad stereotypami w polskiej socjologii, Ruch Prawniczy, Ekonomiczny i Socjologiczny, nr 2 (1979); Z. Mitosek, Stereotyp w przekazie propagandowym (na przykładzie felietonu Adolfa Nowaczyńskiego), [w:] O współczesnej kulturze literackiej, pod red. S. Żółkiewskiego, M. Hopfingera, t. 1, Wrocław 1973; Z. Bokszański, Stereotypy a kultura, Wrocław 1997; M. Kofta, A. Jasińska-Kania, Stereotypy i uprzedzenia. Uwarunkowania psychologiczne i kulturowe, Warszawa 2001; J. Błuszkowski, Stereotypy narodowe w świadomości Polaków. Studium socjologiczno-politologiczne, Warszawa 2003; Stereotypy narodowościowe na pograniczu, pod red. W. Bonusiaka, Rzeszów 2002; R. B. Woźniak, Obraz Niemiec i Niemców w świadomości polskie młodzieży pogranicza, Szczecin 1997. Z prac zawodowych historyków i politologów warto wspomnieć o kilku: Wokół stereotypów Polaków i Niemców, pod red. W. Wrzesińskiego, Wrocław 1991; T. Szarota, Niemcy i Polacy. Wzajemne postrzeganie i stereotypy, Warszawa 1996; J. Dymitrów, Obraz Rosji i Rosjan w propagandzie narodowych socjalistów 1933-1945, Warszawa 1997; R. Michalski, Obraz bolszewizmu Rosji Sowieckiej na łamach prasy pomorskiej w latach 1920-1939, Toruń 1997; Idem, Obraz Rzeszy Niemieckiej na łamach polskiej prasy pomorskiej Drugiej Rzeczypospolitej 1920-1939, Toruń 1995; Idem, Obraz nieprzyjaciół Rzeczypospolitej na łamach prasy pomorskiej w latach 1920-1939 oraz 
od politycznych sympatii odnajdujemy w karykaturach: „żydowskiego pająka”, „niemiecką świnię”, „bolszewickiego-sowieckiego trójgłowego smoka”. Jeszcze większe pole manewru pozostawało w werbalnej części stanowiącej z rysunkiem jedną całość. Mamy tutaj choćby: „grubego, skąpego Żyda”, „Żyda pasożyta”, „Żyda lichwiarza”, „Żyda spekulanta”, „Okrutnego bolszewika”, „Bolszewicką bestię”, „Niemca-Krzyżaka”, etc. ${ }^{14}$. Wielowątkowość i figuratywność wypowiedzi obrażała, wyśmiewała, wyszydzała tworząc skrzywiony, uproszczony i zabarwiony wartościująco obraz rzeczywistości. Inną kwestią, która była obecna w karykaturze politycznej dwudziestolecia międzywojennego jest prognozowanie rzeczywistości. Wielokrotnie napotykamy w prasie tamtego okresu „futurystyczne” wizje lat pięćdziesiątych, sześćdziesiątych a nawet „apokaliptycznego" roku 2000. Były to, jak sądzę nie tyle próby świadomego opartego na racjonalnych przesłankach prognozowania społeczno-politycznego, ile próby swoistej perswazji, wywierania wpływu na świadomość społeczną. Doskonale ilustruje ten przykład wizja roku 1981 na łamach poznańskiego „Pająka”. Polskie waśnie polityczne, spory i ideowe dylematy miały znaleźć swój finał dopiero po śmierci głównych aktorów polskiej sceny politycznej. Widzimy tam między innymi groby: J. Piłsudskiego, N. Barlickiego, W. Witosa, W. Trąmpczyńskigo, W. Korfantego. Nad rysunkiem widnieje napis: „Ziemia święta ich dopiero pojedna. Wizja przyszłości” ${ }^{15}$.

4. Funkcja psychologiczna. Istotną cechą karykatury politycznej jest operowanie katalogiem znaków graficznych, obfitą ilością symboli, metafor, aluzji, przenośni. Ów alfabet, jakim dysponuje karykaturzysta jest jedynym środkiem wyrazu, ekspresji, prezentacji treści. Im bardziej bogaty i zrozumiały dla adresata przekazu katalog środków (symboli) tym większa możliwość panowania nad emocjami, ale również agresją odbiorców. Karykatura, która jak już pisałem wcześniej jest nośnikiem sytuacji komicznych, w sposób pełny może rozładowywać agresję adresatów. Rysunek przedstawiający znielubionego polityka czy też obraz wroga (najczęściej Żyd, Niemiec, Bolsze-

1945-1948, Toruń 1994; Idem, Polska między Niemcami a Rosją. Obraz świata, Rzeczypospolitej i jej sąsiadów na łamach prasy pomorskiej w latach 1920-1939 oraz 1945-1948, Toruń 2000, D. Jarosz, Obraz chłopa w krajowej publicystyce czasopiśmienniczej 1944-1959, Warszawa 1994; K. Wrzesińska, Obraz mniejszości narodowych w poznańskiej prasie konserwatywnej w latach 1918-1939, Poznań 2002; Z. Mazur, Obraz Niemiec w polskich podręcznikach szkolnych do nauczania historii 1945-1989, Poznań 1995.

${ }^{14}$ Szeroki wachlarz werbalnych określeń przytacza I. Kamieńska-Szmaj, Judzi, zohydza, ze czci odziera. Język propagandy politycznej w prasie 1919-1923, Wrocław 1994, s. 99-166.

15 Pająk, nr 19 (1930), s. 1. 
wik-komunista) w sytuacji wywołującej śmiech jest jedynym środkiem, jakim dysponuje odbiorca komunikatu by rozładować własne emocję - niechęć wobec anty-wzoru osobowego. Dla badacza podejmującego problem recepcji i analizy sytuacji komicznej - śmiesznej - wywołującej zadowolenie sześćdziesiąt, siedemdziesiąt lat wcześniej jest jednak nader trudnym zadaniem. To co śmieszyło Polaków kilkadziesiąt lat temu niekoniecznie dzisiaj musi wywoływać śmiech, jest raczej zupełnie odwrotnie. Komizm dwudziestolecia irytuje, bądź też przechodzimy wokół niego zupełnie obojętnie. Wejście w doznania i odczucia ludzi minionej epoki wydaje się pozostawać w sferze indywidualnych (indywidualnych, zatem również dyskusyjnych) domysłów i osobistych - emocjonalnych odczuć.

5. Funkcja komunikacyjna. Karykatura oprócz tego, że jest doskonałym materiałem źródłowym pełni również ważną rolę społeczną. W schemacie komunikacji społecznej, w której umieszczamy karykaturę proces komunikacyjny obejmuje nadawcę (bezpośrednio jest nim karykaturzysta, pośrednio grupa wspierająca np. orientacja polityczna), przekaz (treść komunikatu), kanał i odbiorę (czytelnik gazety-adresat komunikatu) ${ }^{16}$. W ramach funkcji komunikacyjnej karykatura polityczna ma przede wszystkim dwa zadania. Po pierwsze jest katalizatorem zmian, po drugie zaś jest strażnikiem zastanego stanu rzeczywistości społecznej. Tak więc, może inspirować i modelować zmiany, ale również może bronić tradycyjnie zakorzenionych wartości.

Prawem każdego badacza jest zaprezentowanie własnych propozycji warsztatowych. W moim przekonaniu można wyodrębnić kilka składników w trakcie badań nad karykaturą. Po pierwsze należałoby określić nadawcę

${ }^{16} \mathrm{Na}$ temat komunikowania społecznego istnieje już bogata literatura. Warto przywołać chociażby: T. Goban-Klas, Komunikowanie społeczne, Kraków 1978; Idem, Media i komunikowanie masowe. Teorie i analizy prasy, radia, telewizji i Internetu, Warszawa 1999; Zarys teorii procesów i środków komunikowania masowego, Katowice 1985; B. Dobek-Ostrowska, Wprowadzenie do zagadnień komunikacji społecznej, Wrocław 1993; J. Mikołowski-Pomorski, Z. Nęcki, Komunikowanie skuteczne?, Kraków 1983; S. Kuśmierski, Świadomość społeczna, opinia publiczna, propaganda, Warszawa 1980; W Pisarek, T. Goban-Klas, J. Mikułowski-Pomorski, Z. Nęcki, Rola prasy, radia i telewizji w formowaniu się nastrojów społecznych, Zeszyty Prasoznawcze, nr 2, 1980; J. Grzybczak, Czy oddziaływanie mediów jest skuteczne? Stare i nowe teorie, Zeszyty Prasoznawcze, nr 3/4 1995; W. Pisarek, Współczesne orientacje i kierunki badań nad komunikowaniem masowym, Zeszyty Prasoznawcze, nr 2, 1984; M. Niezgoda, A. Szumakowicz, Masowy przekaz a procesy komunikacji społecznej, Zeszyty Prasoznawcze, nr 1, 1983; J. Mikułowski-Pomorski, Informacja i komunikacja. Pojęcia. Wzajemne relacje, Wrocław 1988. Teoria i praktyka masowego komunikowania, pod red. W. Dudka, Katowice 1986; Nauka o komunikowaniu, pod red. B. Dobek-Ostrowskiej, Wrocław 2001. 
przekazu a zatem zapytać: „kto mówi?”. Przed badaczem staje nie lada dylemat. Nie wszystkie karykatury bowiem były podpisane przez ich autorów, niektóre były sygnowane (pierwsze litery imienia i nazwiska), podpisywane pseudonimami artystycznymi lub anonimowe. I z tymi ostatnimi jest najwięcej dylematów. Jest potrzebna wiedza na temat polskiej karykatury, dogłębna znajomość technik rysunku, pociągnięć ołówkiem, bądź kredką ażeby zidentyfikować anonimowego karykaturzystę. Z pewnością w przypadku bardziej znanych artystów, którzy doczekali się własnych biografii, albo pozostawili po sobie katalogi z wystaw sytuacja jest mniej skomplikowana. Niezwykle istotne jest poznanie najważniejszych wydarzeń z biografii karykaturzysty (rodzinne środowisko, krąg przyjaciół, tytuły pism, w których zamieszczał rysunki, polityczne sympatie) w celu precyzyjnej interpretacji treści przekazu. Jeszcze większe znaczenie ma określenie orientacji politycznej danego tytułu prasowego. Wówczas znajomość poszczególnych epizodów z życia karykaturzysty ma mniejsze znaczenie. Tytułem przykładu wiedza o endeckim rodowodzie „Szopki” i „Pająku” skłaniają do wniosku, że prezentowane tam rysunki satyryczne były zgodne z linią polityczną orientacji, którą pismo reprezentowało. Podobnie łatwo można określić prorządowe sympatie „Cyrulika Warszawskiego", którego inicjatorem powstania był płk. Adam Koc ${ }^{17}$, lewicowe nastawienie „Szpilek”, czy chadeckie inklinacje „Nowego Kuriera”. Większe kontrowersje powstają przy sprecyzowaniu orientacji: „Wróbli na Dachu” czy „Ilustrowanego Kuriera Codziennego” (pisma wydawane w koncernie IKC). Również prezentowane tam karykatury nie pozwalają jednoznacznie stwierdzić, czy owe czasopisma można bezdyskusyjnie sklasyfikować politycznie. Czy jednak orientacja polityczna pisma była zgodna z osobiście wyznawanym światopoglądem karykaturzysty? W musimy być świadomi, że w wielu przypadkach zwłaszcza młodzi karykaturzyści, absolwenci Akademii Sztuk Pięknych lub „artyści z prowincji” w ramach „życiowego startu", początków kariery umieszczali swoje rysunki w pismach o obliczu ideowo-politycznym zgoła odmiennym od hołdowanych przez nich wartości politycznych. Tytułem przykładu rysunki: Z. Czermańskiego, E. Lipińskiego, K. Grusa, T. Kleszczyńskiego pojawiały na przestrzeni dwudziestu lat w kilku gazetach. Niejednokrotnie, jak w przypadku K. Grusa, czy M. Berezowskiej, ich autorskie karykatury umieszczano w „prawicowej” „Szopce” i lewicujących „Szpilkach”. Niemniej przeważała sytuacja, w której pisma o wyraźnym tycznie.

17 Od wyborów brzeskich „Cyrulik Warszawski” stał się pismem neutralnym poli- 
obliczu politycznym (np. „Kurier Poznański”, „Nowy Kurier”, „Robotnik”) zatrudniały bądź udostępniały szpalty „własnym sympatykom”. Na uwagę zasługuje również fakt swoistej specjalizacji karykaturzystów. Analizując to zjawisko J. Szwajcer-Jotes pisał: „Specjalizacja w literaturze jest objawem, który nastąpić musiał z natury rzeczy, ze względu na niezwykły rozwój tej dziedziny sztuki. Specjalizacja ta idzie dziś coraz dalej, kształtując się w ten sam sposób co specjalizacja w dziedzinie malarstwa"18. Możemy więc zauważyć, że specjalizacją Z. Czermańskiego i G. Rogulskiego były piękne, przemawiające symboliką i wyrazem karykatury marszałka J. Piłsudskiego. Z. Skwirczyński specjalizował się w karykaturach posłów Sejmu Ustawodawczego oraz ministrów w pierwszym gabinecie W. Witosa, K. Sichulski przenosił na karty papieru postacie posłów do parlamentu wiedeńskiego oraz wybitnych przedstawicieli życia politycznego Galicji, a na przykład J. Szwajcer-Jotes w rysunku satyrycznym przedstawiał pracowników poszczególnych ministerstw oraz wojska.

Po drugie badacz musi sobie odpowiedzieć na pytanie „co mówi?” i „kiedy mówi?" karykatura. Więc jaka jest treść przekazu, jego fabuła. Mamy tutaj do czynienia z bardzo szerokim wachlarzem zagadnień, które mogą stanowić treść karykatury. Zazwyczaj karykatura polityczna odnosi się do aktualnej sytuacji politycznej, bieżących wydarzeń, polityki zagranicznej państwa, sytuacji międzynarodowej, kampanii wyborczych. Wiele karykatur podejmuje problem jednostek - „znanych osobistości”. Przeglądają czasopisma natrafiamy na karykatury wybitnych mężów stanu, polityków, posłów, senatorów, wojskowych, ludzi różnych zawodów, dyplomatów, etc. Wnikliwa analiza treści powinna obejmować przede wszystkim:

- Rozszyfrowanie symboli, znaków i pojęć, którymi posługiwał się karykaturzysta. Badacz musi „rozkodować” siatkę pojęć, rozszyfrować i zrozumieć język autora rysunku. Dobrze odebrać intencje poszczególnych symboli. W polskiej karykaturze politycznej z okresu II Rzeczypospolitej często pojawiały się postacie z mitologii (karły, pegazy, dwugłowe smoki - głowy często przedstawiały twarze nie lubianych, bądź wrogich polityków), zwierzęta, które miały przypisane cechy ludzkie. Najczęściej umieszczano: świnie, szczury, myszy, orły, osły, robaki, pająki, konie, barany, owce, etc.

- Precyzyjne odczytanie kontekstu przedstawianego wydarzenia. Nieprawidłowe odniesienie przedstawionego wydarzenia co do miejsca i czasu może doprowadzić do zafałszowania obrazu jaki się badaczowi kształtuje.

${ }^{18}$ J. Szwajcer-Jotes, op. cit., s. 9. 
- Badacz musi również odpowiedzieć sobie na pytanie, kiedy karykatura powstała. Chodzi tutaj nie tylko o dokładne określenie czasu powstania karykatury i kontekstu historycznego, w którym powstała. Przede wszystkim musi być świadomy faktu, że karykatury umieszczane w gazetach codziennych powstawały znacznie wcześniej przed ich umieszczeniem na szpaltach gazety. A zatem, badacz musi określić jaka jest luka pomiędzy powstaniem karykatury, a jej wydrukowaniem, jakie jest tempo społecznej reakcji na karykaturę. Poza tym istotne będzie również zbadanie jak szybko sam karykaturzysta zareagował na wydarzenie, które stało się treścią rysunku.

- Rozszyfrowani ukrytych w karykaturze postaci i odczytanie przypisywanych im cech i znaczeń. W przypadku karykatury przedstawiającej pojedyncze postacie, zwłaszcza te bardzo charakterystyczne i ogólnie znane, np. J. Piłsudski, W. Witos, I. J. Paderewski, B. Wieniawa-Dłogoszowski, A. Hitler, zadanie jest bardzo proste. Znacznie trudniej rozpoznać „mniej znanych” bądź nie wyróżniających się charakterystycznymi cechami polityków (np. S. Kiernika, T. Nocznickiego, B. Stolarskiego, W. T. Staniszkisa, ks. Sz. Starkiewicza). Jeszcze inna sytuacja występuje, gdy mamy karykaturę zbiorową, przedstawiającą kilka, a czasami kilkanaście postaci, bądź karykaturę odwołującą się do klasyki malarstwa. Posłużmy się dwoma dość charakterystycznymi przykładami. W karykaturze Z. Czermańskiego pt. „Batory pod Pskowem” (wg obrazu J. Matejki), rolę Batorego - wielkiego, niepokonanego wodza przywdziewa się Piłsudski. Wokół niego stoją Janusz Radziwiłł lider konserwatystów w łonie BBWR, adiutant marszałka B. Wieniawa-Długoszowski, hołd składa poseł Stronnictwa Narodowego - Stanisław Stroński, zaś na kolanach klęczy w geście ukorzenia przed Wodzem, „niepokorny” gen. W. Sikorski. Pozostałe dwie postacie właściwie trudno rozpoznać, nawet biegłemu w historii politycznej II Rzeczypospolitej historykowi ${ }^{19}$. Jeszcze trudniejsza jest analiza karykatury Z. Czermańskiego pt. „Bitwa pod Grunwaldem” (wg obrazu J. Matejki). Z obrazka z łatwością rozpoznajemy: A. Hitlera (wcielił się w rolę Wielkiego Mistrza Krzyżackiego Urlicha von Jungingena), gen. B. Wieniawę-Długoszowskiego, H. Goeringa, J. Piłsudskiego. 0 wiele trudniej odnaleźć choćby postacie: ambasadora Rzeczypospolitej w Berilnie J. Lipskiego, premiera L. Kozłowskiego, artystę operowego J. Kiepurę. Rysunek przedstawia również kilkadziesiąt innych postaci, znanych dla ludzi tamtych czasów, jednak dla współczesnych trudnych do rozszyfrowania. Stosunkowo łatwy do

19 Marszałek Piłsudski w 13 karykaturach Zdzisława Czermańskiego, Paryż 1931 (reprint pod tym samym tytułem - wyd. Sanacja 1991 r.). 
odczytania jest również kontekst rysunku. Pokazuje on wiekowe zmagania polsko-niemieckie (wóz Drzymały, w chmurach postać kanclerza Otto von Bismarcka), jednocześnie pokazuje nastrój sielanki, radości i zadowolenia, co stanowiło reakcję „elit” na podpisanie 26 I 1934 deklaracji polsko-niemieckiej o nieagresji. Kontrast jaki stosuje artysta (tradycyjny konflikt - krzyżuje z radością) przemawiać miał do czytelnika w sposób bardzo sugestywny. Czermański sięgając do symbolu-mitu bitwy pod Grunwaldem świadom był jego głębokiego zakorzenienia w świadomości Polaków. Dychotomiczny kontrast był i jest również dla współczesnych zrozumiały ${ }^{20}$.

Pełne odczytanie kontekstu jest jedynie możliwe dopiero wówczas, kiedy potraktujemy go kompleksowo. Nie możemy bowiem zapominać, że karykatura, rozumiana jako rysunek satyryczny stanowi razem z częścią werbalną (napisem pod rysunkiem, komentarzem, dialogiem, monologiem) stanowią jedną całość. Interpretacja samego rysunku bez uwzględnienie umieszczonego pod nim komentarza może doprowadzić do niepełnej analizy. Część werbalna karykatury okazuje się szczególnie ważna wówczas, kiedy badacz nie jest w stanie odczytać aluzji, symboli, przenośni zastosowanych w karykaturze.

Po trzecie należy zadać sobie pytanie „komu mówi?”, to jest kto jest odbiorcą przekazu. Określenie prawdopodobnych i faktycznych odbiorców karykatury jest bardzo trudne. Przede wszystkim musimy wiedzieć, w jakim czasopiśmie opublikowano rysunek. Jeśli możemy określić orientację ideowopolityczną pisma, wówczas z łatwością możemy wskazać na potencjalnych odbiorców. Tytułem przykładu drukowane w wydawnictwie A. Sadzewicz, M. Niklewski i spółka (w tym samym wydawnictwie drukowano „Myśl Narodową” i „Przegląd Wszechpolski”) satyryczno-humorystyczne pismo „Szopka” docierało głównie do sympatyków Związku Ludowo-Narodowego. Natomiast „Cyrulik Warszawski" wspierany przez liberalną inteligencję o proweniencji piłsudczykowskiej trafiał przede wszystkim do przeciwników endecji. Jednak w przypadku niektórych pism codziennych, np. „Kuriera Porannego”, „Tygodnika Ilustrowanego”, „Ilustrowanego Kuriera Codziennego” trudno precyzyjnie stwierdzić, jakim tendencjom politycznym schlebiały. Nie należy również wykluczyć, że pisma o wyraźnym obliczu politycznym były poczytne przez czytelników o odmiennych poglądach lub też neutralnych. Jedynym miernikiem była w tym przypadku funkcja rozrywkowa pisma. Karykatura miała tylko śmieszyć, aluzje i polityczne tło pozostawały na marginesie zainteresowania odbiorcy.

${ }^{20}$ Plansza pt. „Z cyklu: Malarstwo Polskie w aktualnej karykaturze. Bitwa pod Grunwaldem według obraz u Jana Matejki, rysował Z. Czermański”, dodatek do „Wiadomości Literackich", 1934, nr 52. 
Ostatnim ważnym pytaniem węzłowym, na które należałoby sobie odpowiedzieć brzmi: „Z jakim skutkiem?”, czyli jakie są efekty procesu komunikacyjnego. Obliczenie efektów, a więc zbadanie społecznego odbioru rysunku karykaturalnego należy rozpatrywać w kilku aspektach. Po pierwsze, ważne będzie czy przesłanie karykatury odniosło pożądany skutek. Doskonale obrazuje ten proces tzw. karykatura przedwyborcza, promująca ugrupowania i dyskredytująca przeciwników politycznych. Karykatura podobnie jak inne środki wizualnego wyrazu, np. plakat stanowiła również doskonały środek w celu realizacji zadań nałożonych przez propagandę reżimu, obozu politycznego lub pojedynczego polityka. Karykatura także inspiruje pożądane wzory osobowe u aktorów sceny politycznej. Cechy te rzecz jasna ewoluują w ciągu procesu dziejowego, jak również są różne dla polityków różnych odcieni politycznych. Przeglądając tytuły prasowe widzimy tam osobowe wzory: wodza - bohatera - żołnierza, człowieka czynu, obywatela, polityka, kombatanta. Wśród pozytywnych cech osobowych polska karykatura polityczna szczególnie wskazywała na: patriotyzm, uczciwość, szlachetność, czyn, honor, bezinteresowność, fachowość, realizm, pragmatyzm, ideowość, skromność. Ośmieszała natomiast: fałsz, nepotyzm, klientelizm, korupcję, brak fachowości, nieskuteczność, tchórzostwo, łamanie prawa, służalstwo, etc ${ }^{21}$. Można zatem powiedzieć, że karykatura wpływa na kształt kultury politycznej, inspiruje powstawanie wzorów zachowań, przebudowuje normy społeczne ale również chroni tradycyjnie zabezpieczone w świadomości wartości. „Barometrem” i miernikiem społecznych ocen jest oczywiście aprobata

${ }^{21}$ Zob. np. J. Rudziński, Wzory osobowe w niektórych polskich czasopismach Drugiej Rzeczypospolitej, Kwartalnik Historii Prasy Polskiej, 1982, t. XXI, z. 1; Idem, Wzory osobowe polityków w prasie polskiej 1918-1939, ibidem, t. XXXII, z. 3; Idem, Odzwierciedlenie hierarchii wartości $w$ wypowiedziach prasowych. Kilka uwag metodologicznych, Kwartalnik Historii Prasy Polskiej, 1986, t. XXV, z. 4; Idem, Wzory osobowe polityków w „Gazecie Ludowej” $i$ „Głosie Ludu” przed wyborami do sejmu w 1947 r., z. I, Kwartalnik Historii Prasy Polskiej, 1990, t. XXIX, z. 3; A. Paczkowski, Prasa a kultura polityczna w Drugiej Rzeczypospolitej, Kwartalnik Historii Prasy Polskiej, 1978, t. XVII, z. 4; Idem, Prasa w kulturze politycznej Drugiej Rzeczypospolitej. Problemy i propozycje badawcze, Kwartalnik Historii Prasy Polskiej, 1980, t. XIX, z. 2; Idem, Badania historycznoprasowe w zastosowaniu do badań nad dziejami myśli politycznej, [w:] Na warsztatach historyków myśli politycznej, pod red. H. Zielińskiego, Wrocław 1980; G. Kloska, Pojęcia, teorie i badania wartości w naukach społecznych, Warszawa 1982; M. M. Drozdowski, Wartości uniwersalne i kultura narodowa, [w:] Historia i świadomość narodowa, pod red. W. Wesołowskiego, Warszawa 1970; H. Zieliński, Czy istniał model polskiego działacza politycznego? (Piłsudski, Witos, Paderewski, Dmowski), [w:] Dzieje kultury politycznej w Polsce, pod red. J. A. Gierowskiego, Warszawa 1977; R. Czepulis-Rastenis, Wzór osobowy inteligenta polskiego w świetle wspomnień pośmiertnych (1841-1862), Kwartalnik Historyczny, 1978, z. 4. 
lub dezaprobata ze strony odbiorców. Oznacza to, że utrafienie w gusta odbiorców, ich społecznych oczekiwań jest niezwykle istotne. Po drugie karykatura może stymulować społeczne zachowania. Redukować agresję, pobudzać do zmiany zachowań, integrować, czy bronić status quo. Wreszcie karykatura może również tworzyć zwarty katalog zasad moralno-etycznych. Częstokroć rysunek satyryczny bronił uniwersalnych wartości: humanitaryzmu, praw człowieka. Zdarzało się również nierzadko, że raził percepcją anty-wartości, szowinizmu, antysemityzmu.

Przytoczone powyżej propozycje pytań badawczych można rzecz jasna uzupełnić o dodatkowe. Można wysunąć pytanie o środek przekazu: „za pomocą jakiego przekazu?". Odpowiedź wydaje się być truizmem. Nie podlega dyskusji, iż tym środkiem jest karykatura, aczkolwiek dla badacza niezwykle istotny będzie „kanał transmisji”. A zatem powinniśmy dokładnie określić jaką rangą cieszy się prasa wśród innych środków masowego przekazu. Wiemy, że jedynym konkurencyjnym medium w dwudziestoleciu międzywojennym mogło być jedynie radio. Musimy również uwzględnić rangę pisma, jego społeczne oddziaływanie (popularność), sposób kolportażu (marketing i reklama) oraz oblicze społeczno-polityczne. Kolejnym ważnym pytaniem jakie się nasuwa podczas pracy z karykaturą jest określenie celu. A więc pytamy: „w jakim celu - po co?". Istnieje kilka odpowiedzi na to pytanie. Przede wszystkim jak słusznie zauważył T. Szarota powinniśmy starać się zrozumieć klimat epoki, a co za tym idzie „umieć powiązać karykaturę ze stanem psychicznym artysty, spojrzeć na nią jako na manifestację przeżywanych lęków, obaw, zagrożeń, aspiracji, dążeń i nadziei, przejaw stereotypów i frustracji”22. Tak więc karykatura w tym przypadku karykatura odzwierciedla stan umysłu samego twórcy, jego wewnętrzne odczucia, „kondycję duszy artysty”. Częstokroć, zwłaszcza w prasie humorystyczno-satyrycznej karykaturzysta przekazuje czytelnikom-odbiorcom obrazu indywidualne przeżycia. Symbolizm przekazu, środki przez niego użyte są w pełni wolne od „nakazów z góry”. Istnieją również sytuację, zwłaszcza w „prasie politycznej”, kiedy to na karykaturzystę wywierana jest odgórna presja środowiska politycznego, bądź też reżimu rządzącego. Możemy wówczas powiedzieć, że karykaturzysta jest uczestnikiem „przekazu propagandowego”, realizującego „odgórne” cele. Ostatnie pytanie jakie powinien sobie zadać badacz brzmi: „gdzie powstał i rozpowszechniany jest przekaz?". Ma ono szczególne znaczenie dla badań porównawczych nad oddziaływaniem karykatury, a szerzej medium prasowego w różnych pań-

22 T. Szarota, Niemcy i Polacy...., s. 109. 
stwach. W przypadku badań na materiale krajowym ogranicza się do odpowiedzi na pytanie czy dany tytuł ma jedynie zasięg regionalny, czy ogólnokrajowy, czy skierowany jest do wąskiej grupy odbiorców (np. inteligencji), czy grupy bardzo szerokiej? Podsumowując dotychczasowe rozważania metodologiczne możemy skonstruować uproszczony schemat obrazujący przekaz komunikacyjny z wykorzystaniem karykatury.

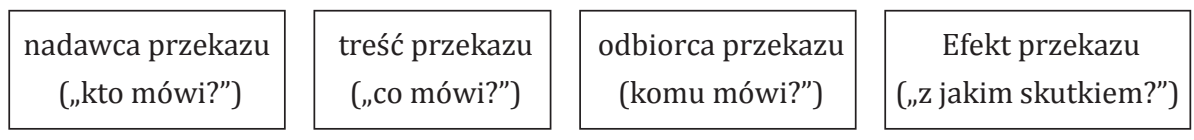

środek przekazu („za pomocą jakiego przekazu?”)

Schemat I. Uproszczony przekaz komunikacyjny z wykorzystaniem karykatury ${ }^{23}$.

Problematyka poruszana $\mathrm{w}$ polskiej karykaturze politycznej okresu II Rzeczypospolitej obejmowała bardzo szerokie spektrum zagadnień, od aktualnej polityki wewnętrznej po sprawy międzynarodowe. Musimy jednak jeszcze poczekać na dogłębną i kompleksową analizę polskiej karykatury politycznej (1918-1939).

Political caricature as a source material for the research on the history of the Second Polish Republic. Research suggestions

In this article author presents his research (methodological) suggestions concerning the political caricature, considered as the source material for the research on the history of the Second Polish Republic. It is hard to overvalue the role of caricature as an iconographic and visual source. Caricature teaches, warns, amuses, but also creates a catalogue of typical behavior. It can become a weapon in political fight. The author has indicated the following functions of caricature: entertaining, sociological, creating and organizing the socio-political reality, psychological and communicative. Every researcher is entitled to present his own methodological proposals. In

${ }^{23}$ Zastosowano w nim klasyczne sformułowania Laswella, znane jako formuła Lasswella, określające podstawowe elementy procesu komunikowania: nadawcę (kto), treść tego, co jest przekazywane (co), kanał, odbiorcę (do kogo) i efekt komunikowania (z jakim skutkiem). 
author's opinion, a number of elements can be distinguished in the research on caricature. At first, the sender of the information should be defined - "who speaks?" Secondly, the researcher has to answer the question "what?" and "when?" the caricature says (the content of the information). Thirdly, the question "who does it speak to?" (the receiver of the information) should be asked. The last essential question to be answered is: "What is the result?" (the outcome of this communication process). The issues addressed in Polish political caricatures in the period of the Second Polish Republic, presented a very broad spectrum, ranging from the current domestic policy to the international affairs. We are still waiting for the in-depth and complex analysis of the Polish political caricature (1918-1939). 